\title{
Wages in a Factor Proportions Time Series Model of the US
}

\author{
Henry Thompson
}

Auburn University

Journal of International Trade and Economic Development, 2010

The theoretical effects of changes in prices and factor endowments on wages in general equilibrium models have been examined under various assumptions. The present paper is the first to estimate wage effects in the context of this theory. The data cover the US real wage, labor force, fixed capital assets, energy input, and prices of manufactures and services from 1949 to 2006 . Estimated input elasticites of the wage are consistent with labor in the middle of the factor intensity ranking, and energy as very intensive in manufacturing. The estimation technique quantifies fundamental influences on the labor market.

Contact information: Economics, 202 Comer Hall, Auburn University AL 36849, 334-844-2910, fax 5999,thomph1@auburn.edu

Thanks for comments and suggestions go to Dimitri Thomakos, Henry Kinnucan, Pete Calcagno, and Calvin Blackwell. 


\section{Wages in a Factor Proportions Time Series Model of the US}

Wages endogenously adjust as markets clear in response to changes in product prices and factors endowments in general equilibrium models of production. These wage effects have been analyzed under various theoretical assumptions but adjustments have not been examined empirically in the context of this fundamental theory.

The present paper estimates US wage adjustments to exogenous changes in inputs of labor, capital, and energy, and changes in prices of manufactures and services from 1949 to 2006 . The estimated difference equation is derived from the comparative static model with three factors and two goods. An error correction model separates adjustment relative to the dynamic equilibrium.

Estimated coefficients reveal information on effective factor intensity and substitution that relate directly to the underlying factor shares, industry shares, and substitution elasticities. The estimates also gauge fundamental influences on the US labor market. Practical issues include the wage effects of the falling price of manufactures, the rising price of services, immigration, investment, and changing energy input.

\section{An applied $3 \times 2$ general equilibrium model}

The factor proportions model based on full employment and competitive pricing is a logical extension of Walras (1874), Heckscher (1919), and Ohlin (1924) as formalized by Samuelson (1953), Jones (1956), Chipman (1966), Jones and Scheinkman (1976), Takayama (1982), and Ethier (1984) and reviewed by Jones and Neary (1984). The present paper applies the model with three factors and two goods of Ruffin (1981), Suzuki (1983), and Thompson (1985, 1993). Applied general equilibrium models are based on observed factor intensity, estimated substitution, and assumptions regarding pricing, industrial organization, factor markets, and employment.

In the present application, inputs of capital $\mathrm{K}$, labor L, and energy $\mathrm{E}$ combine to produce outputs of manufactures $\mathrm{x}_{\mathrm{M}}$ and services $\mathrm{x}_{\mathrm{S}}$ in a competitive three factor, two good model of 
production. Full employment of labor is stated $L=\Sigma_{j} a_{L j} x_{j}$ where $L$ is the labor force and $a_{L j}$ the cost minimizing amount of labor per unit of product $\mathrm{j}$ where $\mathrm{j}=\mathrm{M}, \mathrm{S}$. Differentiate and introduce industry employment shares $\theta_{\mathrm{Lj}}$ and substitution elasticities $\sigma_{\mathrm{ik}}$ in the first equation of the general equilibrium comparative static system (1) with exogenous changes on the right hand side. The second and third equations in (1) capture similar adjustments to exogenous changes in capital $\mathrm{K}$ and energy E inputs.

Competitive pricing of product $\mathrm{j}$ is written $\mathrm{p}_{\mathrm{j}}=\mathrm{a}_{\mathrm{Lj}} \mathrm{W}+\mathrm{a}_{\mathrm{Kj}} \mathrm{r}+\mathrm{a}_{\mathrm{Ej}} \mathrm{e}$ where factor prices are the wage $w$, capital rent $r$, and energy price e. Differentiate and use the cost minimizing envelope theorem to derive the last two equations in (1) where industry shares $\theta_{\mathrm{ij}}$ are factor payment shares across products.

The comparative static model in differences of natural logs is

$$
\left(\begin{array}{ccccc}
\sigma_{\mathrm{LL}} & \sigma_{\mathrm{LK}} & \sigma_{\mathrm{LE}} & \lambda_{\mathrm{LM}} & \lambda_{\mathrm{LS}} \\
\sigma_{\mathrm{KL}} & \sigma_{\mathrm{KK}} & \sigma_{\mathrm{KE}} & \lambda_{\mathrm{KM}} & \lambda_{\mathrm{KS}} \\
\sigma_{\mathrm{EL}} & \sigma_{\mathrm{EK}} & \sigma_{\mathrm{EE}} & \lambda_{\mathrm{EM}} & \lambda_{\mathrm{ES}} \\
\theta_{\mathrm{LM}} & \theta_{\mathrm{KM}} & \theta_{\mathrm{EM}} & 0 & 0 \\
\theta_{\mathrm{LS}} & \theta_{\mathrm{KS}} & \theta_{\mathrm{ES}} & 0 & 0
\end{array}\right)\left(\begin{array}{l}
\mathrm{d} \ln w \\
\mathrm{~d} \ln r \\
\mathrm{dlne} \\
\mathrm{dln} \mathrm{x}_{\mathrm{M}} \\
\mathrm{dlnx}_{\mathrm{S}}
\end{array}\right)=\left(\begin{array}{l}
\mathrm{d} \ln \mathrm{d} \\
\mathrm{d} \ln \mathrm{d} \\
\mathrm{d} \ln \mathrm{d} \\
\mathrm{d} \ln p_{\mathrm{M}} \\
\mathrm{dln} p_{\mathrm{S}}
\end{array}\right) .
$$

The system matrix is the Hessian of constrained neoclassical income maximization. Chang (1979) shows its determinant $\Delta$ is negative with three factors given neoclassical concavity. Cross price substitution elasticities are symmetric $\sigma_{\mathrm{ij}}=\sigma_{\mathrm{ji}}$ and homogeneity implies substitution elasticities sum to zero $\Sigma_{\mathrm{i}} \sigma_{\mathrm{ji}}=0$.

The present focus is wage adjustments to exogenous changes in prices and factor endowments. Let one of these exogenous changes be nonzero, divide both sides of the system (1) by that change, and solve for partial derivatives of the wage with Cramer's rule to find

$$
\begin{aligned}
& \varepsilon_{\mathrm{wL}} \equiv \delta \ln \mathrm{w} / \delta \ln \mathrm{L}=\theta_{\mathrm{KE}} \lambda_{\mathrm{KE}} / \Delta \\
& \varepsilon_{\mathrm{wK}} \equiv \delta \ln \mathrm{w} / \delta \ln \mathrm{K}=-\theta_{\mathrm{KE}} \lambda_{\mathrm{LE}} / \Delta
\end{aligned}
$$




$$
\begin{aligned}
& \varepsilon_{\mathrm{wE}} \equiv \delta \ln w / \delta \ln \mathrm{E}=\theta_{\mathrm{KE}} \lambda_{\mathrm{LK}} / \Delta \\
& \varepsilon_{\mathrm{wM}} \equiv \delta \ln \mathrm{w} / \delta \ln p_{\mathrm{M}}=\left(\theta_{\mathrm{KS}} \varphi_{1}-\theta_{\mathrm{ES}} \varphi_{2}\right) / \Delta \\
& \varepsilon_{\mathrm{wS}} \equiv \delta \ln w / \delta \ln p_{\mathrm{S}}=\left(\theta_{\mathrm{EM} \varphi_{2}}-\theta_{\mathrm{KM}} \varphi_{1}\right) / \Delta
\end{aligned}
$$

where $\theta_{\mathrm{KE}} \equiv \theta_{\mathrm{KM}} \theta_{\mathrm{ES}}-\theta_{\mathrm{EM}} \theta_{\mathrm{KS}}, \theta_{\mathrm{LE}} \equiv \theta_{\mathrm{LM}} \theta_{\mathrm{ES}}-\theta_{\mathrm{EM}} \theta_{\mathrm{LS}}, \theta_{\mathrm{LK}} \equiv \theta_{\mathrm{LM}} \theta_{\mathrm{KS}}-\theta_{\mathrm{LS}} \theta_{\mathrm{KM}}$, and $\lambda_{\mathrm{KE}} \equiv \lambda_{\mathrm{KM}} \lambda_{\mathrm{ES}}-$ $\lambda_{\mathrm{EM}} \lambda_{\mathrm{KS}}$. Homogeneity allows simplification with the terms $\varphi_{1} \equiv\left(\lambda_{\mathrm{KE}}-\lambda_{\mathrm{LK}}\right) \sigma_{\mathrm{LE}}-\left(\lambda_{\mathrm{LE}}+\lambda_{\mathrm{LK}}\right) \sigma_{\mathrm{KE}}$ and $\varphi_{2} \equiv\left(\lambda_{\mathrm{KE}}+\lambda_{\mathrm{LE}}\right) \sigma_{\mathrm{LK}}+\left(\lambda_{\mathrm{LK}}+\lambda_{\mathrm{LE}}\right) \sigma_{\mathrm{EK}}$

The own labor wage elasticity $\varepsilon_{\mathrm{wL}}$ must be negative since $\theta_{\mathrm{KE}}$ and $\lambda_{\mathrm{KE}}$ have the same sign and $\Delta<0$. The wage is the first derivative of the minimized cost function and the negative second derivative $\varepsilon_{\mathrm{wL}}$ reflects neoclassical concavity.

Factor intensities alone determine signs of $\theta_{\mathrm{KE}}, \theta_{\mathrm{LE}}, \theta_{\mathrm{LK}}$, and $\lambda_{\mathrm{KE}}$ and by implication the wage elasticities $\varepsilon_{\mathrm{wK}}$ and $\varepsilon_{\mathrm{wE}}$. If labor and energy are intensive relative to capital in manufacturing then $\lambda_{\mathrm{LK}}>0, \theta_{\mathrm{KE}}<0$, and $\varepsilon_{\mathrm{wE}}>0$.

Either $\varepsilon_{\mathrm{wK}}$ or $\varepsilon_{\mathrm{wE}}$ must be positive, an increase in either capital or energy raising the wage. Increased capital and energy inputs raise the marginal productivity of labor but substitution and output adjustments might not favor the wage for one or the other. Signs of $\varepsilon_{\mathrm{wM}}$ and $\varepsilon_{\mathrm{wS}}$ depend on factor substitution as well as factor intensity. Sizes of all wage elasticitiies also depend on both substitution and intensity.

Partial derivative wage effects are summarized in a single equation as

$$
\mathrm{dln} w=\left(\theta_{\mathrm{KE}}\left(\lambda_{\mathrm{KE}} \mathrm{d} \ln L-\lambda_{\mathrm{LE}} \mathrm{d} \ln \mathrm{K}+\lambda_{\mathrm{LK}} \mathrm{dln} \mathrm{ln}\right)-\varphi_{\mathrm{M}} \mathrm{d} \ln p_{\mathrm{M}}+\varphi_{\mathrm{S}} \mathrm{dln} \mathrm{p}_{\mathrm{S}}\right) / \Delta
$$

where $\varphi_{\mathrm{M}} \equiv \theta_{\mathrm{KS}} \varphi_{1}+\theta_{\mathrm{ES}} \varphi_{2}$ and $\varphi_{\mathrm{S}} \equiv \theta_{\mathrm{EM}} \varphi_{2}-\theta_{\mathrm{KM}} \varphi_{1}$. Empirical specification of the difference equation (3) is

$$
d \operatorname{lnw}=\alpha_{1} d \ln L+\alpha_{2} d \ln K+\alpha_{3} d \ln E+\alpha_{4} d \ln p_{M}+\alpha_{5} d \ln p_{S}+\varepsilon
$$

where $\varepsilon$ is a white noise residual and time subscripts are omitted from the time series variables. Estimated coefficients such as $\alpha_{1}=\varepsilon_{\mathrm{wL}}=\lambda_{\mathrm{EK}} \theta_{\mathrm{EK}} / \Delta$ may reveal information on effective factor intensity and substitution through (2). 
Theoretical expectations are a negative $\alpha_{1}$ and at least one positive sign for $\alpha_{2}$ or $\alpha_{3}$. Price elasticities $\alpha_{4}$ and $\alpha_{5}$ can have any of the four possible sign patterns depending on factor intensity and substitution as shown by Thompson (1985).

The present paper estimates wage equation (4) with an intercept term to gauge other potential wage influences in a series of error correction models.

\section{Difference stationarity}

The data in Figure 1 are from the US National Economic Accounts of the Bureau of Economic Analysis (2007) except Btu energy input E from the US Department of Energy (2007). The wage $\mathrm{w}$ is derived from employee compensation averaged across the labor force $\mathrm{L}$ and deflated by the consumer price index. The capital stock $\mathrm{K}$ is the deflated net stock of fixed capital assets.

\section{* Figure $1 *$}

Prices of manufactures $\mathrm{p}_{\mathrm{M}}$ and services $\mathrm{p}_{\mathrm{S}}$ are indices relative to the consumer price index. Part of the $68 \%$ decrease in $\mathrm{p}_{\mathrm{M}}$ is due to import competition. Quite the opposite, $\mathrm{p}_{\mathrm{S}}$ increased $59 \%$ over the period and services have been increasingly exported. The relative price of services $\mathrm{p}_{S} / \mathrm{p}_{\mathrm{M}}$ increased about five times and the output of services relative to manufactures increased by half according to output indices.

Difference stationarity is required to estimate the difference equation (4). Tests in Table 1 start with the simplest specification of a difference stationary Dickey-Fuller DF test with no constant and proceed until difference stationarity cannot be rejected, adding a constant, time trend, and lags of the dependent variable through the augmented Dickey-Fuller tests with two lags ADF(2) are necessary for labor $\mathrm{L}$ and the price of manufactures $\mathrm{p}_{\mathrm{m}}$. Critical statistics are in the last row. Residuals of the DF tests are tested for white noise, specifically for autocorrelation with DurbinWatson DW statistics and for heteroskedasticity with $\mathrm{ARCH}(1)$ tests as reported in Table 1.

\footnotetext{
* Table $1 *$
} 
None of the variables are AR(1) stationary in levels and none are difference stationary by simple Dickey-Fuller DF tests with no constant. The price of services $\operatorname{lnp}_{\mathrm{S}}$ in Figure 2 is difference stationary by the Dickey-Fuller DFc test with a constant given the F statistic relative to the critical $\varphi$.

Energy input $\ln E$ is difference stationary by the ADF test that adds a time trend $t$ and the lagged dependent variable $\Delta \mathrm{x}_{-1}$. The wage $\operatorname{lnw}$ and capital input $\operatorname{lnK}$ are difference stationary in $\operatorname{ADF}(2)$ tests with the added lag $\Delta \mathrm{x}_{-2}$. Differences of the variables are plotted in Figure 2.

* Figure $2 *$

The labor force $\operatorname{lnL}$ has autocorrelated residuals or significant coefficients in all DF tests, and the price of manufactures $\ln p_{M}$ has consistently positive own DF coefficients. These two series plotted in Figure 3 are, however, difference stationary with a 1975 structural break by the Perron (1989) test reported in the last column of Table 1.

\section{* Figure 3 *}

There is no evidence of autocorrelation in the residuals of these difference stationary tests relative to the critical Durbin-Watson statistics DW $=1.40,2.57$ and no heteroskedasticity according to $\mathrm{ARCH}(1)$ tests. The series are all I(1) processes with unit roots suggesting the regression of difference equation (4) will produce reliable results.

\section{Wage error correction models}

Table 2 reports the spurious regression in levels. The regression passes the Engle-Granger EG (1987) test reported in the last column, suggesting the variables are cointegrated. Campbell and Perron (1991) show the EG test has low power to reject the null hypothesis of no cointegration but Kremers, Ericsson, Dolado (1991) and Banerjee (1995) point out that a successful ECM provides further evidence of cointegrated variables.

\section{* Table $2 *$}

The first row in Table 3 reports the structural equation (4) estimated as the difference model

$$
\Delta \operatorname{lnw}=\alpha_{1} \Delta \operatorname{lnL}+\alpha_{2} \Delta \operatorname{lnK}+\alpha_{3} \Delta \operatorname{lnE}+\alpha_{4} \Delta \operatorname{lnp}_{\mathrm{M}}+\alpha_{5} \Delta \ln p_{\mathrm{S}}+\alpha_{6} \mathrm{D}+\alpha_{7} \mathrm{D} \Delta \ln \mathrm{L}+\alpha_{8} \mathrm{D} \Delta \operatorname{lnp}_{\mathrm{M}}+\varepsilon
$$


where D is the 1975 structural break associated with L and $\mathrm{p}_{\mathrm{M}}$. Coefficients of D and its interactions are insignificant in the first row. Coefficients are interpreted as comparative static arc elasticities with other exogenous changes equal to zero. The own labor $\Delta \ln L$ elasticity is negative and elastic. Both capital $\Delta \operatorname{lnK}$ and energy $\Delta \ln E$ elasticities are positive. The range of critical DW values for no autocorrelation is 1.43 to 2.57 and the difference model falls in the indecisive range, casting some doubt on parameter significance. Also, heteroskedasticity is revealed by the $\mathrm{ARCH}(1)$ test.

\section{* Table $3 *$}

The theoretical model has no constant in (4) but adding a constant gauges other potential influences on the wage. The constant also detrends the wage although that does not seem necessary given the difference stationary series. The second row in Table 3 reports this difference model with a significant constant and similar coefficients except a stronger labor force effect before and a much weaker effect after the 1975 break. The price of manufactures $\mathrm{p}_{\mathrm{M}}$ loses significance. Explanatory power is slightly reduced but heteroskedasticity is dampened.

The third row in Table 3 reports the ECM including the residual from the spurious model in Table 2. There is a significant cointegrating effect, the negative coefficient indicating the wage adjusting relative to the dynamic relationship. Coefficients are similar to the difference model. The structural break D and its interactions remain insignificant. Adjustment to the dynamic equilibrium reflected by the error correction coefficient strengthens the net wage elasticity. No explanatory power is added relative to the difference model, ambiguity in autocorrelation remains in the DW statistic, and $\mathrm{ARCH}(1)$ heteroskedasticity is stronger.

The ECM with a constant is reported in the last row of Table 3. Coefficients are similar to the ECM without a constant although the labor force L effect is stronger before and weaker after the break. There is no autocorrelation or heteroskedasticity implying reliable statistics and this ECM is included in the model comparison in Table 6. 


\section{A lagged wage error correction model}

The dynamic adjustment process is extended to lags of differences in the lagged error correction model $\mathrm{ECM}_{-1}$ in Table 4. Explanatory power increases relative to the ECM and both autocorrelation and heteroskedasticity disappear. Elasticities of labor L, energy E, and the price of services $\mathrm{p}_{\mathrm{S}}$ are stronger, and energy $\mathrm{E}$ has a lagged effect. The capital $\mathrm{K}$ elasticity is insignificant for the first lag and weaker for the second lag relative to the ECM. The price of manufactures $\mathrm{p}_{\mathrm{M}}$ has no effect. The structural break D interacted with labor L is again significant implying a much weaker effect after 1975. The cointegrating coefficient is over twice as strong in its second lag. Regressions with further lags reveal no significant effects suggesting wage adjustment is complete after two years.

\footnotetext{
* Table $4 *$
}

Each exogenous effect is separated into a difference and an error correction effect in the lagged $\mathrm{ECM}_{-1}$. For instance, labor $\Delta \operatorname{lnL}$ has a wage effect of -1.83 and an error correction effect of $0.53 \times 0.69=-0.37$, the two summing to -2.20 . Coefficients of the $\mathrm{ECM}_{-1}$ model are calculated and included in the model comparison in Table 6 along with t-statistics derived through error propagation.

\section{A double difference wage error correction model}

The ambiguous autocorrelation of the difference model suggests it can be utilized in an error correction model in double differences. In the first row of Table 3 there is a significant EngleGranger EG statistic of $-5.37 *(\mathrm{DW}=1.79, \mathrm{ARCH}(1)=0.98)$. With no constant term, the coefficient of each double difference variable equals the difference coefficient in (4).

The first row in Table 5 reports the double difference model. There is no autocorrelation or heterskedasticity, an advantage over the difference model. The labor force L effect is stronger before and slightly positive after the 1975 break. The effects of capital K and the price of 
manufactures $\mathrm{p}_{\mathrm{M}}$ disappear. Including the constant in the second row of Table 5 does not affect results.

\section{* Table $5 *$}

The third row of Table 5 reports the double difference error correction model $\mathrm{ECM}_{2}$ with the residual of the difference model as the error correction variable. There is no autocorrelation or heterskedasticity. Wage elasticities of the labor force L, energy E, and the price of services $\mathrm{p}_{\mathrm{S}}$ are similar to other models but effects of capital $\mathrm{K}$ and the price of manufactures $\mathrm{p}_{\mathrm{M}}$ disappear. The break in labor input implies a weaker effect after 1975. The model with a constant in the second row produces nearly identical coefficients.

The error correction effect is sizeable and negative indicating a vigorous error correction adjustment toward the dynamic equilibrium. Effects of all differences feed through the error correction process. As an example, the error correction effect of energy input is $-0.72 \times-0.74=0.53$ making its total effect $0.65+0.53=1.18$. Coefficients and $t$-statistics of the double difference $\mathrm{ECM}_{2}$ are included in the Table 6 model comparison.

\section{Revealed factor intensity and substitution}

Wage elasticities are summarized in Table 6 for the error correction model ECM in Table 3, the lagged $\mathrm{ECM}_{-1}$ in Table 4, and the double difference $\mathrm{ECM}_{2}$ in Table 5. Results without constants are reported but those with constants are similar. Only significant coefficients enter derivations and t-statistics are reported in Table 6 from standard errors estimated with error propagation calculations. Coefficients are similar across models and not far out of line with coefficients of the spurious model in levels, which would be interpreted as point estimates of elasticities. Consider averages of the three models in the last row of Table 6 for the following discussion.

\footnotetext{
* Table $6 *$
} 
The input elasticity estimates reveal labor as the middle factor in the intensity ranking. Wage elasticities $\left(\varepsilon_{\mathrm{wL}} \varepsilon_{\mathrm{wK}} \varepsilon_{\mathrm{wE}}\right)$ have signs $(-++)$ implying the terms $\left(\lambda_{\mathrm{KE}} \lambda_{\mathrm{LE}} \lambda_{\mathrm{LK}}\right)$ in (2) have signs (-+ ). The two factor intensity rankings consistent with these signs are

$$
\lambda_{\mathrm{EM}} / \lambda_{\mathrm{ES}}>\lambda_{\mathrm{LM}} / \lambda_{\mathrm{LS}}>\lambda_{\mathrm{KM}} / \lambda_{\mathrm{KS}}
$$

and its reverse. The high input of energy in manufacturing suggests (6). The larger size of $\varepsilon_{\mathrm{wE}}$ relative to $\varepsilon_{\mathrm{wK}}$ implies $\lambda_{\mathrm{LK}}>-\lambda_{\mathrm{LE}}>0$ implying $\lambda_{\mathrm{LM}} / \lambda_{\mathrm{LS}}$ is closer to $\lambda_{\mathrm{KM}} / \lambda_{\mathrm{KS}}$ than $\lambda_{\mathrm{EM}} / \lambda_{\mathrm{ES}}$. Manufacturing is then very energy intensive, consistent with observed energy inputs. This result lends credence to the competitive general equilibrium model, worthy of note given the frequently stated opinion that factor proportions theory is empirically irrelevant.

One of the cross price elasticities $\left(\sigma_{\mathrm{KE}}, \sigma_{\mathrm{LE}}, \sigma_{\mathrm{LK}}\right)$ can be negative indicating technical complements but otherwise factors must be substitutes. There is an inconclusive literature on whether capital is a complement or substitute with energy.

The negative manufacturing price effect $\varepsilon_{\mathrm{wM}}$ implies $\theta_{\mathrm{KS}} \varphi_{1}-\theta_{\mathrm{ES}} \varphi_{2}>0$ and the positive $\varepsilon_{\mathrm{wS}}$ implies $\theta_{\mathrm{EM}} \varphi_{2}-\theta_{\mathrm{KM}} \varphi_{1}<0$ from (2) implying $\left(\theta_{\mathrm{KS}}+\theta_{\mathrm{KM}}\right) \varphi_{1}>\left(\theta_{\mathrm{ES}}+\theta_{\mathrm{EM}}\right) \varphi_{2}$ or $\varphi_{1}>\varphi_{2}$ since industry shares sum to one.

If capital and energy were complements, substitution elasticities $\left(\sigma_{\mathrm{KE}} \sigma_{\mathrm{LE}} \sigma_{\mathrm{LK}}\right)$ would have signs $(-++)$ implying $\varphi_{1}<0$ and $\varphi_{2}<0$ as well. Homogeneity implies $\sigma_{\mathrm{LK}}+\sigma_{\mathrm{EK}}=-\sigma_{\mathrm{KK}}>0$ or $\sigma_{\mathrm{LK}}$ $>-\sigma_{\mathrm{EK}}$, and $\varphi_{2}<0$ implies $\sigma_{\mathrm{LK}}>\left(-\left(\lambda_{\mathrm{LE}}+\lambda_{\mathrm{LK}}\right) / \lambda_{\mathrm{LK}}\right) \sigma_{\mathrm{EK}}$ which may be more restrictive. This condition implies there has to be "strong" substitution between capital and labor, in other words a large enough $\sigma_{\text {LK }}$. This result is consistent with Thompson (1995) who shows factor intensity plays a larger role than substitution in theoretical wage adjustments.

\section{Gauging wage sensitivity}

Sizes of wage effects can be gauged by means and standard deviations of changes. For instance, the mean change $1.4 \%$ of the labor force $\Delta \operatorname{lnL}$ and its standard deviation $0.5 \%$ suggest the range of wage changes $1.9 \%$ to $0.9 \%$. The average labor elasticity -2.28 before the 1975 break 
implies an average wage adjustment of $-3.2 \%$ with range $-4.3 \%$ to $-2.1 \%$. After 1975 the average wage elasticity of -0.66 implies an average wage reduction of $0.9 \%$ with range $-1.3 \%$ to $-0.6 \%$.

The conclusion is that steady increases in the labor force over the period have put continuous downward pressure on the wage, especially prior to 1975. Since then, labor market flexibility has increased.

Immigration contributes to the increases in the labor force although the amount is difficult to pin down. Assuming half of the immigrants obtaining legal status plus located aliens enter the labor force, immigration accounts for up to $1 / 2$ of the yearly increase in the labor force. That assumption would imply annual immigration lowered the wage by $-1.6 \%$ before 1975 but by only $-0.5 \%$ since then evaluated at the mean.

The mean capital stock change $\Delta \ln K$ of $3.5 \%$ with its standard deviation $2.2 \%$ and the average 0.28 elasticity imply an average wage increase of $1.0 \%$ with range $1.6 \%$ to $0.4 \%$. The mean energy input change of $\Delta \ln E$ of $2.0 \%$, standard deviation $2.8 \%$, and 1.10 energy elasticity imply an average wage increase of $2.2 \%$ with range $5.3 \%$ to $-0.9 \%$. Increases in the labor force are more than offset after 1975 by increased labor demand due to investment and increased energy input. Before 1975, however, labor market competition dominated with a net wage decrease.

The mean change in the price of manufactures $\Delta \ln p_{M}-2.0 \%$ and its standard deviation $1.7 \%$ imply the range $-0.3 \%$ to $-3.7 \%$. The elasticity of -0.36 then implies an average wage adjustment of $0.7 \%$ with range $1.3 \%$ to $0.1 \%$. While the positive wage effect of the falling price of manufactures might seem paradoxical, services is revealed by the coefficients relating to (6) as labor intensive.

The mean and standard deviation of the change in the price of services $\Delta \operatorname{lnp}_{\mathrm{S}}$ are both $0.8 \%$ implying the range $1.6 \%$ to $0 \%$ and its 1.31 elasticity implies a $1.0 \%$ average wage effect with range $2.1 \%$ to $0 \%$. These annual manufacturing and services price effects are consistent with the labor intensive services in the revealed intensity ranking (6). 
The mean net change in the wage predicted by the mean changes in all exogenous variables is $1.7 \%$. The actual mean wage change is $2.1 \%$ suggesting the model fairly successfully explains typical wage changes over the sample period.

Thompson (2005) presents parametric relaxations of the competitive assumptions of the factor proportions model that lead to results similar to the competitive model. This parametric approach to imperfect competition offers specifications for future empirical research related to the present competitive model.

\section{Conclusion}

Estimates of the wage equation in the present three factor, two good production model for the US between 1949 and 2006 model reveal labor as the middle factor relative to capital and energy, and energy as very intensive in manufacturing. The wage effect of the typical increase in the US labor force was almost $-4 \%$ before 1975 but has reduced to about $-1 \%$ since then. Immigration accounts for perhaps half of these wage reductions.

The rising price of services has raised the wage about $1 \%$ annually and the falling price of manufactures has had about the same positive wage effect. The underlying expansion of the service sector has supported the wage with the relative price of services increasing over five times.

The wage has also increased an average of $1 \%$ annually due to investment and over twice that amount due to increased energy input. The expected diminishing energy input over the coming decades does not bode well for labor although continued specialization in the service sector would relieve pressure on labor's falling marginal productivity in manufacturing.

The present regression results are consistent with substitution between all inputs or with capital and energy as complements in production, an issue in the applied production literature. The present approach to revealing implications of effective substitution has the potential to contribute to the applied production literature. 
The present approach also has potential to refine general equilibrium models of production. Estimated parameters allow the implications of various theoretical assumptions to be compared directly. Adjustment processes for various countries and time periods can be compared. The data can be expanded to include other factors of production including labor skills, natural resources, and sector specific capital. Outputs can be disaggregated. The various equations of the general equilibrium production model, including adjustments in all factor prices and outputs, can be estimated. 


\section{References}

Banerjee, Anindya (1995) "Dynamic Specification and Testing for Unit Roots and Cointegration," in K.D. Hoover (ed) Macroeconometrics, Kluwer, chapter 12.

Bureau of Economic Analysis (2007) National Economic Accounts, Department of Commerce webpage, www.bea.gov/national/nipaweb/SelectTable.asp?Selected=N

Chang, Winston (1979) "Some Theorems of Trade and General Equilibrium with Many Goods and Factors," Econometrica 47, 709-26.

Chipman, John (1966) "A Survey of the Theory of International Trade: Part 3, The Modern Theory," Econometrica 34, 18-76.

Department of Energy (2007) Energy Overview, Energy Information Agency webpage, www.eia.doe.gov/emeu/aer/overview.html

Dickey, David and Wayne Fuller (1979) "Distribution of the Estimates for Autoregressive Time Series with a Unit Root," Journal of the American Statistical Association 74, 427-31.

Kremers, J.J., N.R. Ericsson, and Juan Dolado (1992) “The Power of Co-Integration Tests,” Oxford Bulletin of Economics and Statistics 54, 325-48.

Engel, Robert and Clive Granger (1987) "Cointegration and Error-Correction: Representation, Estimation, and Testing,” Econometrica 55, 251-76.

Ethier, Wilfred (1984) "Higher Dimensional Issues in Trade Theory," in Ron Jones and Peter Kenen (eds) Handbook of International Economics, vol. 1, Amsterdam: North Holland, 131-84

Heckscher, Eli (1919) “The Effect of Foreign Trade on the Distribution of Income," Ekonomisk Tidskrift.

Jones, Ron (1965) “The Structure of Simple General Equilibrium Models," Journal of Political Economy 73, 57-72.

Jones, Ron and Neary, Peter (1984) "The Positive Theory of International Trade," in Handbook of International Trade, vol. 1, Ron Jones and Peter Kenen (eds.), Amsterdam: North Holland.

Jones, Ron and José Scheinkman (1977) “The Relevance of the Two-Sector Production Model in Trade Theory," Journal of Political Economy 85, 909-35.

Ohlin, Bertil (1924) The Theory of Trade, translated in Harry Flam and June Flanders, HeckscherOhlin Trade Theory, MIT Press, 1991, 73-214.

Perron, Pierre (1989) "The Great Crash, the Oil Shock, and the Unit Root Hypothesis," Econometrica 57, 1361-1401. 
Rassekh, Fahad (1992) "The Role of International Trade in the Convergence of Per Capita GDP in the OECD, 1950-1985," International Economic Journal 6, 1-15.

Ruffin Roy (1981) "Trade and Factor Movements with Three Factors and Two Goods," Economics Letters 7, 177-82.

Samuelson, Paul (1953) "Prices of Factors and Products in General Equilibrium," Review of Economic Studies 21, 1-20.

Stolper, Wolfgang and Paul Samuelson (1941) "Protection and Real Wages," Review of Economic Studies 9, 58-73.

Suzuki Katsuhiko (1983) "A Synthesis of the Heckscher-Ohlin and Neoclassical Models of International Trade: A Comment,” Journal of International Economics 14, 141-44.

Takayama, Akira (1982) "On Theorems of General Competitive Equilibrium of Production and Trade: A Survey of Recent Developments in the Theory of International Trade," Keio Economic Studies 19, 1-38.

Thompson Henry (1985) "Complementarity in a Simple General Equilibrium Production Model," Canadian Journal of Economics 16, 616-21.

Thompson, Henry (1993) “The Magnification Effect with Three Factors, Keio Economic Studies 20, 57-64.

Thompson, Henry (1995) "Factor Intensity versus Factor Substitution in a Specified General Equilibrium Model,” Journal of Economic Integration, 283-97.

Thompson, Henry (2003) "Robustness of the Stolper-Samuelson Factor Intensity Price Link," in Handbook of International Trade, edited by Kwan Choi, Blackwell.

Thompson, Henry (2005) "Income Redistribution, Trade Prices, and International Capital in Simulated Trade Models, in WTO and World Trade: Challenges in a New Era, edited by Geunter Heiduk and Kar-yiu Wong, Springer-Verlag.

Thompson, Henry (2007) “An Empirical Measure of Factor Intensity when there are Many Factors and Many Products," The International Trade Journal 21, 109-19.

Walras, Léon (1874) Elements of Pure Economics, 1954 translation of 1926 edition, Richard Irwin. 
Figure 1. Data series

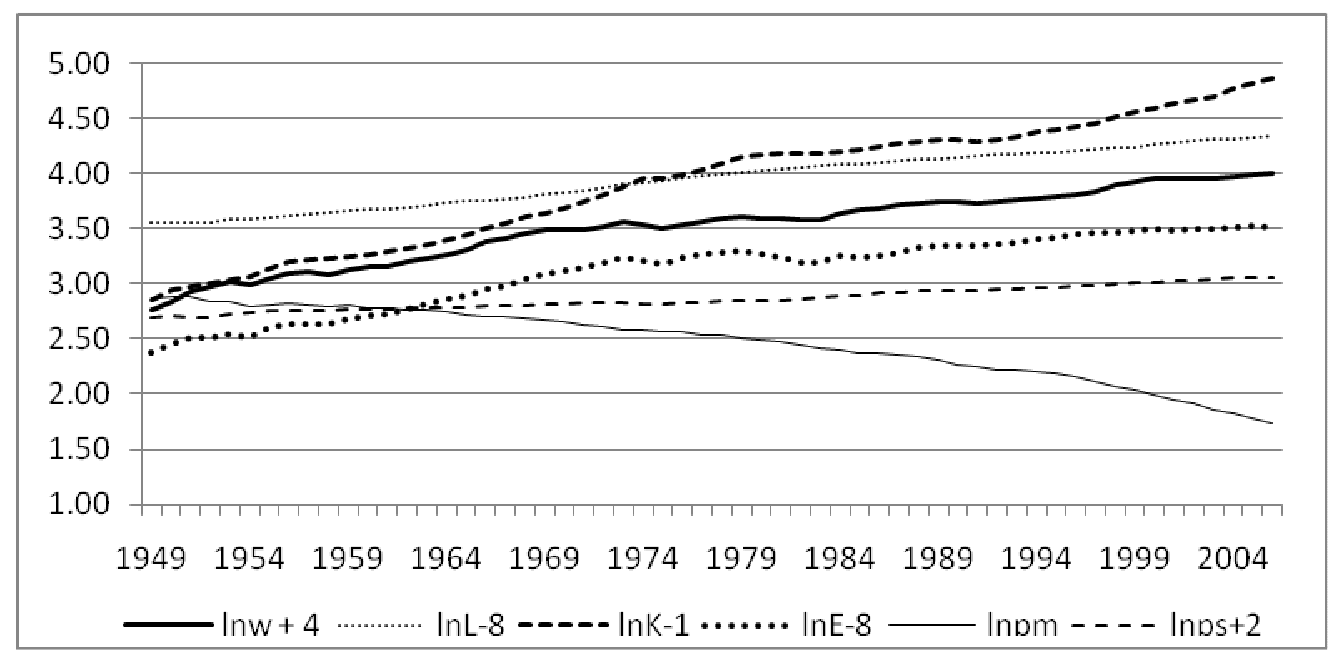

Figure 2. Difference Stationary

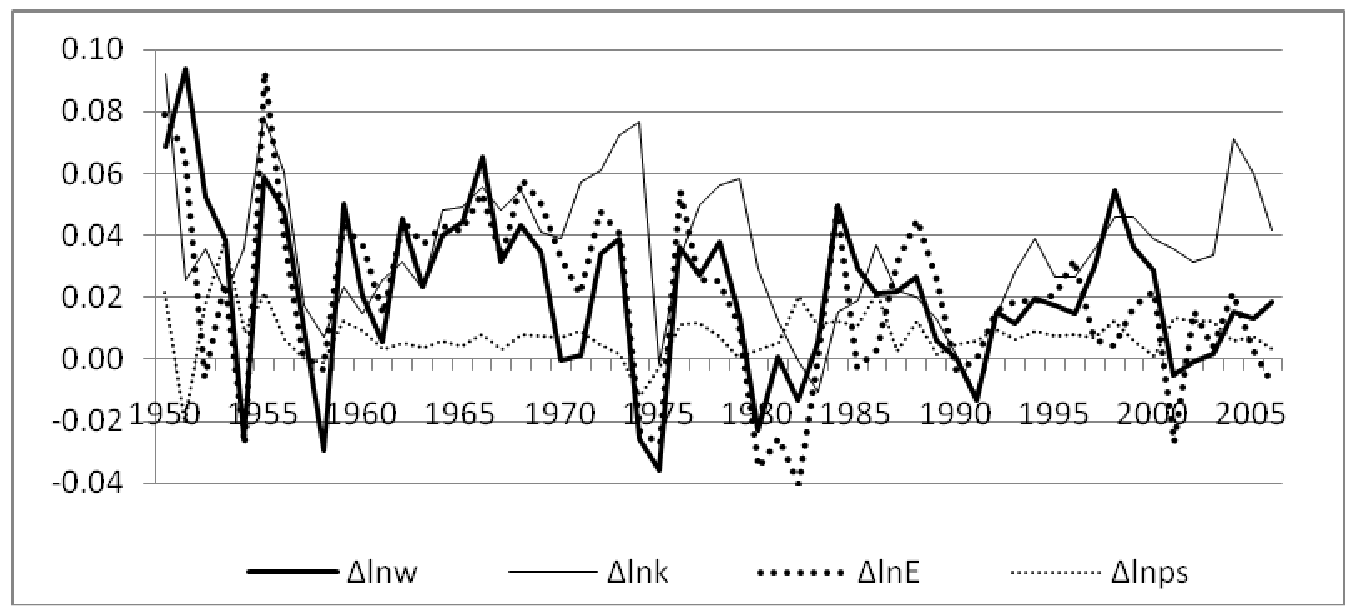

Figure 3. Difference Stationary with 1975 Structural Break

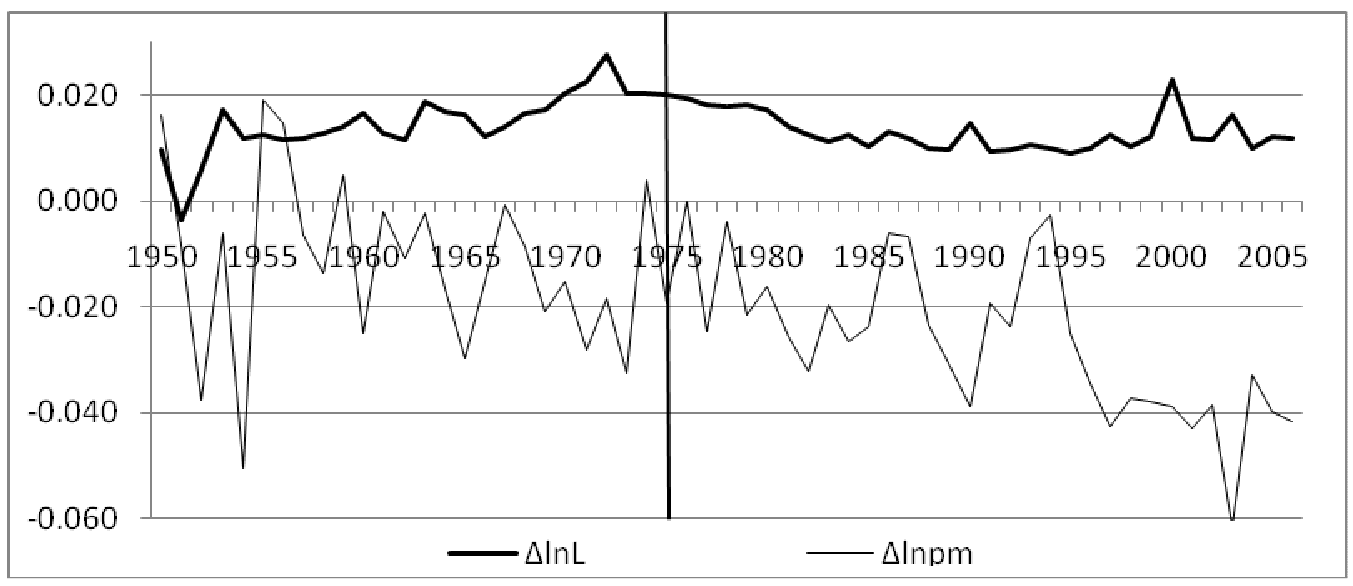


Table 1. Stationarity Analysis

\begin{tabular}{|c|c|c|c|c|c|c|c|}
\hline & $\mathrm{AR}(1)$ & $\overline{\mathrm{DF}}$ & $\overline{D F c}$ & $\overline{\mathrm{DFt}}$ & ADF & $\mathrm{ADF}(2)$ & $\begin{array}{c}\text { Perron } \\
1975\end{array}$ \\
\hline $\begin{array}{c}\text { lnw } \\
\text { F } \\
\text { DW } \\
\text { ARCH(1) }\end{array}$ & $1.02>1$ & 5.76 & $-2.61^{*}$ & $\begin{array}{c}-2.44 \\
5.43 *\end{array}$ & $\begin{array}{l}-3.45 \\
7.51^{*}\end{array}$ & $\begin{array}{l}-2.65 \\
5.20 \\
2.03 \\
0.50\end{array}$ & \\
\hline $\begin{array}{c}\operatorname{lnL} \\
F \\
\text { DW } \\
\text { ARCH(1) }\end{array}$ & $1.00>1$ & 21.6 & $\begin{array}{c}-0.23 \\
0.05 \\
0.79 \#\end{array}$ & $\begin{array}{c}-0.49 \\
0.20 \\
0.79 \#\end{array}$ & $\begin{array}{l}-1.28 \\
11.2^{*}\end{array}$ & $\begin{array}{l}-1.44 \\
8.46^{*}\end{array}$ & $\begin{array}{l}-2.43 \\
\\
1.87 \\
0.94 \\
\end{array}$ \\
\hline $\begin{array}{c}\operatorname{lnK} \\
F \\
\text { DW } \\
\text { ARCH(1) }\end{array}$ & $1.01>1$ & 11.3 & $\begin{array}{c}-0.95 \\
0.89 \\
1.13 \#\end{array}$ & $\begin{array}{c}-1.24 \\
1.07 \\
1.11 \#\end{array}$ & $\begin{array}{l}-1.97 \\
6.21^{*}\end{array}$ & $\begin{array}{r}-1.53 \\
5.73 \\
1.69 \\
0.89\end{array}$ & \\
\hline $\begin{array}{c}\ln E \\
F \\
\text { DW } \\
\text { ARCH(1) }\end{array}$ & $\begin{array}{c}0.98<1 \\
1.66 \\
2.16^{*}\end{array}$ & 5.18 & $-3.28 *$ & $\begin{array}{c}-1.43 \\
5.42 *\end{array}$ & $\begin{array}{r}-1.13 \\
3.07 \\
2.00 \\
1.51\end{array}$ & & \\
\hline $\begin{array}{c}\ln p_{\mathrm{m}} \\
\mathrm{F} \\
\mathrm{DW} \\
\text { ARCH(1) }\end{array}$ & $1.03>1$ & $-3.60 *$ & 5.59 & 1.03 & 0.99 & 1.18 & $\begin{array}{l}-0.48 \\
\\
1.78 \\
0.99\end{array}$ \\
\hline $\begin{array}{c}\operatorname{lnp}_{\mathrm{s}} \\
\mathrm{F} \\
\mathrm{DW} \\
\text { ARCH( }(1)\end{array}$ & $1.01>1$ & $-5.71 *$ & $\begin{array}{c}-0.95 \\
0.91 \\
1.82 \\
0.36 \\
\end{array}$ & & & & \\
\hline $\begin{array}{c}\text { Critical values } \\
\tau_{\mathrm{DF}} \\
\varphi .90 \\
\text { DW } 1.43,2.57\end{array}$ & & -1.95 & $\begin{array}{c}-2.93 \\
4.86\end{array}$ & $\begin{array}{c}-3.50 \\
5.13\end{array}$ & $\begin{array}{c}-3.50 \\
6.73\end{array}$ & $\begin{array}{c}-3.50 \\
6.73\end{array}$ & $\begin{array}{l}\tau_{\text {Perron }} \\
-3.76\end{array}$ \\
\hline
\end{tabular}


Table 2. Spurious Regression

\begin{tabular}{|c|c|c|c|c|c|c|c|}
\hline constant & $\operatorname{lnL}$ & $\operatorname{lnK}$ & $\ln \mathrm{ln}$ & $\operatorname{lnp}_{\mathrm{M}}$ & $\ln \mathrm{s}_{\mathrm{S}}$ & & $\mathrm{EG}_{\tau}-3.18$ \\
\hline $3.95^{* *}$ & $-0.69^{* * *}$ & $0.25^{* * *}$ & $0.61^{* * *}$ & -0.01 & $1.29^{* * *}$ & $\operatorname{adjR}^{2} .996$ & $-3.32^{*}$ \\
$(2.35)$ & $(-4.63)$ & $(3.36)$ & $(10.7)$ & $(-0.10)$ & $(6.91)$ & DW 0.62(+) & DW 1.46 \\
& & & & & & ARCH 2.64*** & ARCH 1.15 \\
\hline
\end{tabular}

Table 3. Difference Model and ECM in $\Delta$ lnw

\begin{tabular}{|c|c|c|c|c|c|c|c|c|c|c|}
\hline & $\Delta \ln \mathrm{L}$ & $\Delta \ln K$ & $\Delta \ln \mathrm{E}$ & $\Delta \ln p_{M}$ & $\Delta \ln p_{\mathrm{s}}$ & $\mathrm{D}$ & $\mathrm{D} \Delta \ln \mathrm{L}$ & $\mathrm{D} \Delta \ln p_{\mathrm{M}}$ & $\operatorname{Res}_{-1}$ & \\
\hline $\begin{array}{c}\text { Difference } \\
\text { no } \\
\text { constant }\end{array}$ & $\begin{array}{c}-1.24 * * * \\
(-3.10)\end{array}$ & $\begin{array}{c}0.31 * * * \\
(2.81)\end{array}$ & $\begin{array}{c}0.74 * * * \\
(8.14)\end{array}$ & $\begin{array}{l}-0.37^{*} \\
(-1.86)\end{array}$ & $\begin{array}{c}0.49^{*} \\
(1.81)\end{array}$ & $\begin{array}{c}-0.01 \\
(-0.50)\end{array}$ & $\begin{array}{c}1.05 \\
(1.20)\end{array}$ & $\begin{array}{c}0.23 \\
(0.81)\end{array}$ & & $\begin{array}{c}\operatorname{adjR}^{2} .763 \\
\text { DW 1.39(?) } \\
\text { ARCH 1.87* }\end{array}$ \\
\hline $\begin{array}{c}0.30^{* * *} \\
(3.30)\end{array}$ & $\begin{array}{c}-2.46^{* * * *} \\
(-4.74)\end{array}$ & $\begin{array}{c}0.23 * * \\
(3.20)\end{array}$ & $\begin{array}{c}0.65^{* * * *} \\
(7.53)\end{array}$ & $\begin{array}{c}-0.21 \\
(-1.09)\end{array}$ & $\begin{array}{c}0.45^{*} \\
(1.85)\end{array}$ & $\begin{array}{c}-0.03 * * \\
(-2.30)\end{array}$ & $\begin{array}{l}2.29 * * \\
(2.59)\end{array}$ & $\begin{array}{c}0.09 \\
(0.34)\end{array}$ & & $\begin{array}{c}\operatorname{adjR}^{2} .738 \\
\text { DW } 1.49 \\
\text { ARCH } 0.93\end{array}$ \\
\hline $\begin{array}{c}\text { ECM } \\
\text { no } \\
\text { constant }\end{array}$ & $\begin{array}{c}-1.22 * * * \\
(-3.18)\end{array}$ & $\begin{array}{l}0.26^{* *} \\
(2.45)\end{array}$ & $\begin{array}{c}0.72 * * * \\
(8.20)\end{array}$ & $\begin{array}{l}-0.45^{* *} \\
(-2.31)\end{array}$ & $\begin{array}{c}0.69 * * \\
(2.44)\end{array}$ & $\begin{array}{c}-0.01 \\
(-0.71)\end{array}$ & $\begin{array}{c}1.09 \\
(1.29)\end{array}$ & $\begin{array}{c}0.29 \\
(1.06)\end{array}$ & $\begin{array}{c}-0.25^{* *} \\
(-2.28)\end{array}$ & $\begin{array}{c}\operatorname{adjR}^{2} .780 \\
\text { DW } 1.37(?) \\
\text { ARCH } 2.43^{* *}\end{array}$ \\
\hline $\begin{array}{c}0.03^{* * *} \\
(3.11)\end{array}$ & $\begin{array}{c}-2.34 * * * \\
(-4.64)\end{array}$ & $\begin{array}{l}0.19^{*} \\
(1.93)\end{array}$ & $\begin{array}{c}0.64 * * * \\
(7.62)\end{array}$ & $\begin{array}{c}-0.28 \\
(-1.53)\end{array}$ & $\begin{array}{l}0.71^{*} \\
(2.64)\end{array}$ & $\begin{array}{c}-0.03 * * \\
(-2.36)\end{array}$ & $\begin{array}{l}2.22^{* *} \\
(2.59)\end{array}$ & $\begin{array}{c}0.15 \\
(0.58)\end{array}$ & $\begin{array}{c}-0.21^{* *} \\
(-2.04)\end{array}$ & $\begin{array}{c}\operatorname{adjR}^{2} .738 \\
\text { DW } 1.49 \\
\text { ARCH } 0.93\end{array}$ \\
\hline
\end{tabular}

Table 4. Lagged ECM-1 in $\Delta$ Inw

\begin{tabular}{|c|c|c|c|c|c|c|c|c|}
\hline & $\Delta \ln \mathrm{L}$ & $\Delta \ln K$ & $\Delta \ln \mathrm{E}$ & $\Delta \ln p_{M}$ & $\Delta \ln p_{\mathrm{S}}$ & D & $\mathrm{D} \Delta \ln \mathrm{L}$ & $\mathrm{D} \Delta \ln \mathrm{p}_{\mathrm{M}}$ \\
\hline $\begin{array}{c}\text { no } \\
\text { constant }\end{array}$ & $\begin{array}{c}-1.83 * * * \\
(-3.56)\end{array}$ & $\begin{array}{c}0.04 \\
(0.26)\end{array}$ & $\begin{array}{c}0.78 * * * \\
(10.6)\end{array}$ & $\begin{array}{c}0.13 \\
(-0.75)\end{array}$ & $\begin{array}{c}1.06^{* * * *} \\
(3.75)\end{array}$ & $\begin{array}{l}-0.02^{*} \\
(-1.69)\end{array}$ & $\begin{array}{l}1.55 * * \\
(2.05)\end{array}$ & $\begin{array}{c}0.01 \\
(0.04)\end{array}$ \\
\hline \multirow[t]{4}{*}{$\begin{array}{c}0.01 \\
(0.91)\end{array}$} & $\begin{array}{c}-2.04 * * * \\
(-3.62)\end{array}$ & $\begin{array}{c}0.07 \\
(0.53)\end{array}$ & $\begin{array}{c}0.75 * * * \\
(9.40)\end{array}$ & $\begin{array}{c}-0.11 \\
(-0.59)\end{array}$ & $\begin{array}{c}0.97 * * * \\
(3.20)\end{array}$ & $\begin{array}{l}-0.03^{*} \\
(-1.92)\end{array}$ & $\begin{array}{l}1.82 * * \\
(2.24)\end{array}$ & $\begin{array}{c}-0.02 \\
(-0.07)\end{array}$ \\
\hline & $\Delta \ln L_{-1}$ & $\Delta \ln K_{-1}$ & $\Delta \ln E_{-1}$ & $\Delta \ln p_{M-1}$ & $\Delta \ln p_{\mathrm{S}-1}$ & $\operatorname{Res}_{-1}$ & $\operatorname{Res}_{-2}$ & \\
\hline & $\begin{array}{c}0.34 \\
(0.70)\end{array}$ & $\begin{array}{l}0.18^{*} \\
(1.79)\end{array}$ & $\begin{array}{l}0.14^{*} \\
(1.69)\end{array}$ & $\begin{array}{c}-0.14 \\
(-0.86)\end{array}$ & $\begin{array}{c}0.33 \\
(1.34)\end{array}$ & $\begin{array}{c}0.11 \\
(0.83)\end{array}$ & $\begin{array}{c}-0.53^{* * *} \\
(-3.87)\end{array}$ & $\begin{array}{c}\operatorname{adjR}^{2} .846 \\
\text { DW } 2.02 \\
\text { ARCH } 0.79\end{array}$ \\
\hline & $\begin{array}{c}0.20 \\
(0.38)\end{array}$ & $\begin{array}{c}0.14 \\
(1.20)\end{array}$ & $\begin{array}{c}0.12 \\
(1.38)\end{array}$ & $\begin{array}{c}-0.12 \\
(-0.72)\end{array}$ & $\begin{array}{c}0.26 \\
(0.26)\end{array}$ & $\begin{array}{c}0.11 \\
(0.74)\end{array}$ & $\begin{array}{c}-0.50 * * * \\
(-3.48)\end{array}$ & $\begin{array}{c}\operatorname{adjR}^{2} .782 \\
\text { DW } 2.11 \\
\text { ARCH } 0.52\end{array}$ \\
\hline
\end{tabular}


Table 5. Double Difference Model and $\mathrm{ECM}_{2}$ in $\Delta^{2} \operatorname{lnw}$

\begin{tabular}{|c|c|c|c|c|c|c|c|c|c|c|}
\hline constant & $\Delta^{2} \operatorname{lnL}$ & $\Delta^{2} \ln K$ & $\Delta^{2} \ln \mathrm{E}$ & $\Delta^{2} \ln p_{M}$ & $\Delta^{2} \ln p_{\mathrm{S}}$ & $\mathrm{D}$ & $\mathrm{D} \Delta^{2} \ln \mathrm{L}$ & $\mathrm{D} \Delta^{2} \ln p_{\mathrm{M}}$ & $\operatorname{Res}_{\Delta}$ & \\
\hline & $\begin{array}{c}-3.16^{* * *} \\
(-3.51)\end{array}$ & $\begin{array}{c}0.13 \\
(1.09)\end{array}$ & $\begin{array}{c}.67 * * * \\
(8.39)\end{array}$ & $\begin{array}{c}0.00 \\
(0.00)\end{array}$ & $\begin{array}{l}0.64 * * \\
(2.32)\end{array}$ & $\begin{array}{c}0.00 \\
(0.27)\end{array}$ & $\begin{array}{l}3.35 * * \\
(2.57)\end{array}$ & $\begin{array}{c}-0.11 \\
(-0.41)\end{array}$ & & $\begin{array}{c}\operatorname{adjR}^{2} .667 \\
\text { DW } 2.24 \\
\text { ARCH } 0.80\end{array}$ \\
\hline $\begin{array}{c}0.00 \\
(0.38)\end{array}$ & $\begin{array}{c}-3.23 * * * \\
(-3.49)\end{array}$ & $\begin{array}{c}0.13 \\
(1.07)\end{array}$ & $\begin{array}{c}0.67 * * * \\
(8.33)\end{array}$ & $\begin{array}{c}0.00 \\
(0.00)\end{array}$ & $\begin{array}{l}0.65^{* *} \\
(2.33)\end{array}$ & $\begin{array}{c}-0.00 \\
(-0.12)\end{array}$ & $\begin{array}{l}3.42 * * \\
(2.57)\end{array}$ & $\begin{array}{c}-0.11 \\
(-0.41)\end{array}$ & & $\begin{array}{c}\operatorname{adjR}^{2} .682 \\
\text { DW 2.25 } \\
\text { ARCH } 1.01\end{array}$ \\
\hline $\begin{array}{c}\mathrm{ECM}_{2} \\
\text { no } \\
\text { constant }\end{array}$ & $\begin{array}{c}-2.35 * * * \\
(-3.09)\end{array}$ & $\begin{array}{c}0.05 \\
(0.50)\end{array}$ & $\begin{array}{c}.65^{* * * *} \\
(10.1)\end{array}$ & $\begin{array}{c}-0.23 \\
(-1.61)\end{array}$ & $\begin{array}{c}0.83 * * * \\
(3.63)\end{array}$ & $\begin{array}{c}0.00 \\
(0.27)\end{array}$ & $\begin{array}{l}2.64 * * \\
(2.44)\end{array}$ & $\begin{array}{c}0.31 \\
(1.29)\end{array}$ & $\begin{array}{c}-0.72 * * * \\
(-4.91)\end{array}$ & $\begin{array}{c}\operatorname{adjR}^{2} .768 \\
\text { DW } 1.83 \\
\text { ARCH } 0.82\end{array}$ \\
\hline $\begin{array}{c}0.00 \\
(1.21)\end{array}$ & $\begin{array}{c}-2.48 * * * \\
(-3.25)\end{array}$ & $\begin{array}{c}0.04 \\
(0.44)\end{array}$ & $\begin{array}{c}0.66^{* * * *} \\
(10.2)\end{array}$ & $\begin{array}{l}-0.24^{*} \\
(-1.67)\end{array}$ & $\begin{array}{c}0.89 * * * \\
(3.81)\end{array}$ & $\begin{array}{c}-0.00 \\
(-0.76)\end{array}$ & $\begin{array}{l}2.79 * * \\
(2.58)\end{array}$ & $\begin{array}{c}0.32 \\
(1.35)\end{array}$ & $\begin{array}{c}-0.75 * * * \\
(-5.05)\end{array}$ & $\begin{array}{c}\operatorname{adjR}^{2} .791 \\
\text { DW } 1.83 \\
\text { ARCH } 1.12 \\
\end{array}$ \\
\hline
\end{tabular}

Table 6. Comparison of ECM Wage Elasticities

\begin{tabular}{|c|c|c|c|c|c|}
\hline & $\mathrm{L} /$ break & $\mathrm{K}$ & $\mathrm{E}$ & $\mathrm{p}_{\mathrm{M}}$ & $\mathrm{p}_{\mathrm{S}}$ \\
\hline $\mathrm{ECM}$ & $-1.39^{* * *}$ & $0.32^{* * *}$ & $0.87^{* * *}$ & $\begin{array}{c}-0.45^{* *} \\
(2.32)\end{array}$ & $\begin{array}{c}1.01^{* * *} \\
(7.83)\end{array}$ \\
& $(6.78)$ & $(3.52)$ & $(17.8)$ & & \\
\hline $\mathrm{ECM}_{-1}$ & $-2.20^{* * *} /-0.65$ & $0.32^{* * *}$ & $1.25^{* * *}$ & 0 & $1.74^{* * *}$ \\
& $(4.14) /(0.70)$ & $(2.76)$ & $(8.93)$ & & $(5.01)$ \\
& & & & & \\
\hline $\mathrm{ECM}_{2}$ & $-3.24 * * * / 0.59^{*}$ & $0.22^{*}$ & $1.18^{* * *}$ & $-0.27^{* * *}$ & $\begin{array}{c}1.18^{* * *} \\
\end{array}$ \\
& $(-5.41) /(1.59)$ & $(1.33)$ & $(168)$ & $(-4.43)$ & $(6.98)$ \\
\hline average & $-2.28 /-0.88$ & 0.28 & 1.10 & -0.36 & 1.31 \\
& & & & & \\
\hline
\end{tabular}

